\title{
Effect Alkaline Additive to Polyester-based Composite for Biomedical Applications
}

\author{
Ismail Ibrahim Marhoon $^{1 *}$, Waleed Asim Hanna ${ }^{2}$ \\ ${ }^{1}$ Materials Engineering Department, College of Engineering, Al-Mustansiriyah University, Baghdad-Iraq \\ ${ }^{2}$ Materials Engineering Department, University of Technology, Baghdad-Iraq
}

\begin{abstract}
A composite material was prepared by adding $\mathrm{K}_{2} \mathrm{CO}_{3}$ particles $(<53 \mu \mathrm{m}$ in size) to $0.3-1.8 \mathrm{wt} \%$ unsaturated polyester resin. The maximum values of tensile strength, hardness, impact energy, and water absorption (\%) were $56.885 \mathrm{~N} / \mathrm{mm}^{2}$ at $0.3 \mathrm{wt}^{\mathrm{m}}, 86.4 \mathrm{Shore}$ $D$ at $1.5 w t \%, 0.43 \mathrm{~J}$ at $0.9 \mathrm{wt} \%$, and $0.9831 \%$ at $15 \mathrm{wt} \%$ compared with neat values, i.e., $37.4742 \mathrm{~N} / \mathrm{mm}^{2}$, $84 \mathrm{Shore} \mathrm{D}$, $0.33 \mathrm{~J}$, and $0.263 \%$, respectively.
\end{abstract}

Keywords: Unsaturated polyester,matrix composite, bio-material, Bio-composite , Composite physical property , Composite mechanical property

\section{Introduction}

Traumas, diseases, and surgical intervention lead to the necessity of alternatives to damaged tissues of the body to continue the natural function of members and maintain health through these alternative parts. The alternatives are usually structural parts of the body, such as the knee, hip, bone, joints, and supporting bone and teeth $[1,2]$.

The histocompatibility of materials, such as metals, ceramics, and polymers, had led to their use in surgical implants as alternatives to parts affected or supported by bones. However, metals and ceramics are very limited and nonbiodegradable. Conversely, polymeric materials (polymers) have drawn increasing attention and are increasingly used in textile engineering because of their biodegradability and easy processability $[4,3]$.

The most important applications of these materials are sutures, transporters for distributing drug into the body, supporting pillars of the bones, or as a substitute for the affected bone [5]. Unknown period of survival under variable stresses is one of the basic restrictions for utilizing ceramics in the medicinal cases. This limitation leads to the defects and growth of the notch, as well as the failure of ceramics, in many medical applications [3].

Single-phase engineering materials, such as metals and ceramics, do not have the vital attributes similar to the properties of living tissues, such as bones, because some vital chemical and physical properties do not co-exist in single-phase materials. However, these vital attributes can co-exist in several materials so a composite material is necessary [6].

Therefore, composites that possess some features may be appropriate for various applications. These materials gained prominence among various engineering materials, considering that the composites combine the properties of two or more materials to surpass the disadvantages of individual materials. In addition, composite properties can be controlled either through the type or ratio of the material or through the design and methods of manufacturing the material [2].

The polymer-based composite is prepared from modern materials used in most engineering and technological applications. One of the most main requirements for the use of these materials are good durability, high performance, and resistance to corrosion and internal and external stresses acting on them. Moreover, the materials should be able to resist environmental conditions, such as temperature and pressure $[1,2]$.

In 1998, Liu et al. studied the chemical linkage of a composite strengthened with hydroxyapatite (HA). The floor was made from double polymeric material composed of polyethylene glycol and polypropylene taffeta. A cofactor on the link has been noted to improve the mechanical properties, such as tensile strength and modulus of elasticity [7]. In 2003, Kai- Uwe studied the improvement of the bioactivity for polypropylene that was strengthened by HA as substitute for affected and amputated bones. He used two sets of samples, one of which was strengthened with nanoparticles, and the second set was strengthened with microbes. Moreover, he successfully strengthened the sample with nanoparticles by cultivation within the body of the animal for eight weeks [8]. In 2010, Jayabalan et al. studied the effect of adding nanoparticles from powder calcined HA. were strengthened with weight fraction (30 wt\%) HA to unsaturated polyester resin as base material, and two different materials in sizes and forms are used rod-like shaped calcined HA with particle size of less than $100 \mathrm{~nm}$ and spherical shaped calcined HA with particle size of less than $200 \mathrm{~nm}$. The results show that the unsaturated polyester resin was strengthened by fillings from the powder calcined HA nanoparticles, which provided an interfacial bonding surface. The base material with rod-like-shaped nanoparticles showed the best coefficients and biomechanical strengths [9]. In 2010, Khalaf et al. studied the impact of adding HA particles during preparation, as well as before and after calcination, as fillings to strengthen various grains with varied weight fractions $(2.5,5,7.5,10$, 12.5 , and 15) and to unsaturated polyester resin strengthened with powder calcined HA. This process resulted in higher 


\section{International Journal of Science and Research (IJSR) \\ ISSN (Online): 2319-7064 \\ Index Copernicus Value (2013): 6.14 | Impact Factor (2014): 5.611}

values of resistance to pretensions, coefficient of flexibility, percentage of extension at break, compression resistance, factor compression, shock resistance, fracture strength, and hardness compared with resin strengthened with uncalcined HA powder. These characteristics are due to the impact of the calcined and uncalcined HA with different sizes [10].

The mechanical properties of unsaturated polyester are lower compared with metals and ceramic materials. A problem associated with this material when implanted in the living body was its low mechanical properties. Second, the degradation by non-enzymatic hydrolysis of ester bonds in their backbone reduces the local $\mathrm{pH}$, which in turn may induce tissue irritation and inflammation as well as systematic injury at the site of operation, leading to failure in the performance of the implant. Polymer acidity should be regulated by normalization.

Thus, adding an alkaline additive, such as carbonates, to polyester can provide a $\mathrm{pH}$ buffering effect at the polymer surface, thus avoiding an unfavorable environment for new bone growth. Moreover, these additives may play an important role in improving the engineering properties of unsaturated polyester considering its effects as filler modifiers. This work is focused on studying the addition effect especially at low weight fractions of potassium carbonate $\left(\mathrm{K}_{2} \mathrm{CO}_{3}\right)$ in the range of $0.3-1.8 \mathrm{wt} \%$ on some mechanical and physical properties, namely, tensile, impact energy, hardness, and water absorption, of the unsaturated polyester.

\section{Experimental Part}

\subsection{Materials}

$\mathrm{K}_{2} \mathrm{CO}_{3}$ was produced by Thomas Baker (Chemical) Ltd., India (Table 1). Matrix material, unsaturated polyester resin, hardener methyl ethyl ketone peroxide (MEKP), and cobalt octoate drops of opaque liquid as an accelerator were produced by Saudi Industrial Resins (SIR). Table 2 lists the matrix materials used in the study.

Table 1: Physical and chemical properties of the $\mathrm{K}_{2} \mathrm{CO}_{3}$ according to producer specifications

\begin{tabular}{|c|c|c|c|c|c|}
\hline Material & Solubility & Density & $\begin{array}{c}\text { Bulk } \\
\text { density }\end{array}$ & $\begin{array}{c}\mathrm{pH} \\
\text { value }\end{array}$ & $\begin{array}{c}\text { Particle } \\
\text { size }\end{array}$ \\
\hline $\mathrm{K}_{2} \mathrm{CO}_{3}$ & $\begin{array}{c}1125 \mathrm{~g} / \mathrm{l} \\
\left(20^{\circ} \mathrm{C}\right)\end{array}$ & $\begin{array}{l}.43 \mathrm{~g} / \mathrm{cm}^{3} \\
\left(20^{\circ} \mathrm{C}\right)\end{array}$ & $\begin{array}{c}750 \\
\mathrm{~kg} / \mathrm{m}^{3}\end{array}$ & $\begin{array}{l}1.5-2.5 \\
(50 \mathrm{~g} / \mathrm{l}, \\
\mathrm{H}_{2} \mathrm{O}, \\
\left.20^{\circ} \mathrm{C}\right)\end{array}$ & $<53 \mu \mathrm{m}$ \\
\hline
\end{tabular}

Table 2: Physical properties of unsaturated polyester resin according to producer specifications

\begin{tabular}{|c|c|c|c|c|}
\hline Material & Viscosity & $\begin{array}{c}\text { Specific } \\
\text { gravity }\end{array}$ & $\begin{array}{c}\text { Thermal } \\
\text { conductivity }\end{array}$ & $\begin{array}{c}\text { Volume } \\
\text { shrinkage }\end{array}$ \\
\hline $\begin{array}{c}\text { Unsaturated } \\
\text { polyester } \\
\text { resin }\end{array}$ & $\begin{array}{c}500-600 \\
\mathrm{cps}\end{array}$ & $\begin{array}{c}1.13 \\
\mathrm{~g} / \mathrm{cm}^{3} \\
\left(25^{\circ} \mathrm{C}\right)\end{array}$ & $\begin{array}{c}0.17 \\
\mathrm{~W} / \mathrm{m} .{ }^{\circ} \mathrm{C}\end{array}$ & $7 \%$ \\
\hline
\end{tabular}

\subsection{Composite Fabrication}

$\mathrm{K}_{2} \mathrm{CO}_{3}$ was added carefully and gradually to the solution of pre-accelerated unsaturated polyester resin to avoid the loss of $\mathrm{K}_{2} \mathrm{CO}_{3}$. The composite mixture was stirred and experiential to ensure that the $\mathrm{K}_{2} \mathrm{CO}_{3}$ was mixed well with the matrix or until a uniform mixture was obtained. The mixture was mixed continuously and slowly for approximately $20 \mathrm{~min}$ at room temperature to avoid bubbling during mixing. MEKP was added to the mixture, and the mixture was stirred for $5 \mathrm{~min}$. The mixture was cast in a glass mold by pouring from one corner into the mold to avoid bubble creation, which causes cast damage. Uniform pouring was continued until the mold was filled to the necessary level. The mixture was left in the mold for $24 \mathrm{~h}$ at room temperature to harden. Then, the cast was positioned inside a dryer oven overnight at $45{ }^{\circ} \mathrm{C}$. This step was important to reveal complete polymerization (best coherency) and relieve residual stresses. The samples were cut according to the standard dimensions for each test, namely, tensile, impact, hardness, and water absorption tests, using different cutting tools. The above procedure was followed in preparing the composites at specified weight fractions of $\mathrm{K}_{2} \mathrm{CO}_{3}$.

Water absorption test was accomplished according to ASTM D 570-98 where the specimens were dried for $24 \mathrm{~h}$ at $50{ }^{\circ} \mathrm{C}$. Conditioned specimens were then immersed in distilled water at room temperature. Then, the specimens were taken from the water after $24 \mathrm{~h}$ and wiped with a cotton tissue to remove surface water. The samples were then weighed to the nearest $0.0001 \mathrm{~g}$. Tensile test was accomplished according to ASTM D638M-87b [11,12]. Impact test was accomplished according to ISO-180 [13]. Hardness test was accomplished using Shore hardness D and according to ASTM D 2240. All tests were conducted at room temperature.

\section{Results and Discussion}

\subsection{Mechanical Evaluation}

\subsubsection{Tensile Strength}

Figure 1 shows the tensile strength and weight fraction relationship of $\mathrm{K}_{2} \mathrm{CO}_{3}$, which were added to the unsaturated polyester. The addition of $\mathrm{K}_{2} \mathrm{CO}_{3}$ filler particles evidently affected the tensile strength of the material. The maximum tensile strength of $\mathrm{K}_{2} \mathrm{CO}_{3}$ reached $56.885 \mathrm{~N} / \mathrm{mm}^{2}$ at $0.3 \mathrm{wt} \%$ compared with the tensile strength of the neat polymer, which is $37.474 \mathrm{~N} / \mathrm{mm}^{2}$. The percentage in weight represents the critical weight fraction, beyond which the strength decreases with increase in filler content [14]. The results also showed that the tensile strength increased as the weight fractions increased from $0.3 \mathrm{wt} \%$ to $0.9 \mathrm{wt} \%$, but decreased as the volume fraction increased beyond $0.9 \mathrm{wt} \%$. The decrease in strength may be due to the fact that the non-wetting of the filler particles with the matrix and the non-uniform distribution of the particles [15], weak interfacial bonding at $\mathrm{K}_{2} \mathrm{CO}_{3}$ and polyester matrix interfaces, agglomeration of $\mathrm{K}_{2} \mathrm{CO}_{3}$ particles, and defects, such as observed porosity [16] as a consequence of excessive particles that were not well distributed in the polymer, created the stress intensity in the polymer matrix and decreased the tensile strength [17]. 


\section{International Journal of Science and Research (IJSR) ISSN (Online): 2319-7064}

Index Copernicus Value (2013): 6.14 | Impact Factor (2014): 5.611

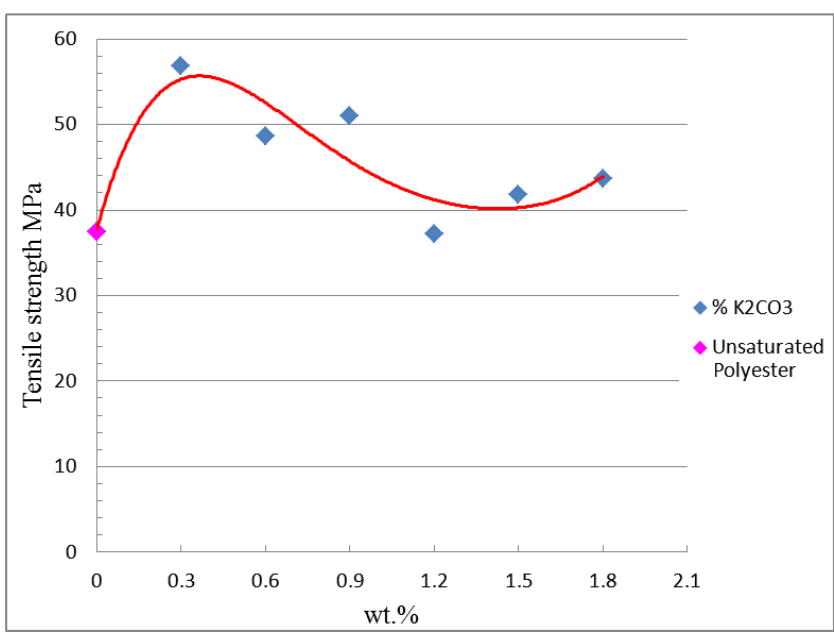

Figure 1: Relationship between tensile strength and weight fraction of the filler particles at $0.3-1.8 \mathrm{wt} \%$

\subsubsection{Hardness}

Figure 2 shows the relationship between hardness and weight fraction of the filler particles of $\mathrm{K}_{2} \mathrm{CO}_{3}$, which were added to the unsaturated polyester resin. The results showed that hardness increased with increasing weight fraction of filler particles, and reached its maximum amount of 86.4 at $1.5 \mathrm{wt} \%$ of $\mathrm{K}_{2} \mathrm{CO}_{3}$. This hardness value is consistent with the hardness of the reference polymer (84) because of the increased wettability and bonding (interaction) between the matrix and the filler particles.

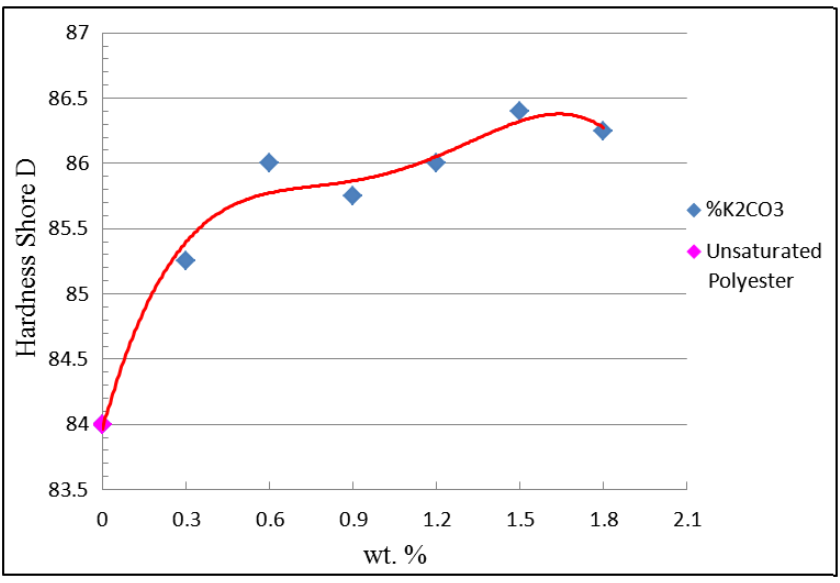

Figure 2: Relationship between the Shore $\mathrm{D}$ hardness and weight fraction of the filler particles at $0.3-1.8 \mathrm{wt} \%$

\subsubsection{Impact Energy}

Figure 3 shows the relationship between impact energy and weight fraction of $\mathrm{K}_{2} \mathrm{CO}_{3}$. The maximum impact energy of $\mathrm{K}_{2} \mathrm{CO}_{3}$ reached $0.43 \mathrm{~J}$ at $0.9 \mathrm{wt} \%$ compared with the impact energy of the reference, which is $0.33 \mathrm{~J}$ after $0.9 \mathrm{wt} \%$. The results had revealed that the impact energy decreased with increasing weight fraction of filler particles for all sets of composite materials. Rapid crack propagation is introduced through the material when a composite is exposed to an impact. When such crack propagation encounters filler particles in the filled composites, the filler particles can absorb the energy and halt the crack propagation if the filler matrix interaction is strong. Thus, a weak interfacial adhesion cannot resist crack propagation as efficiently as the polymer alone and therefore a catastrophic crack is propagated, lowering the impact strength $[15,18]$. This phenomenon eventually leads to a lowering in the impact strength of the composites as loading of the filler increases. For the particle composites, as the filler loading increases, the tendency for agglomeration also becomes weaker, leading to weaker interfacial regions. The agglomerates then act as stress concentration points or crack initiation sites. Therefore, a reduction in impact strength on increasing filler loading is expected. As the filler agglomeration increases, the interfacial adhesion because of the particles, which may represent points of localized stress concentration, from which the failure will begin [15]. This phenomenon is mainly due to the decrease in elasticity of the material because of filler addition, thus reducing the deformability of matrix and consequently the ductility in the skin area, so the composite tends to form a weak structure. Similarly, an increase in concentration of filler reduces the ability of the matrix to absorb energy and thus reduce the toughness, decreasing impact energy [19-21].

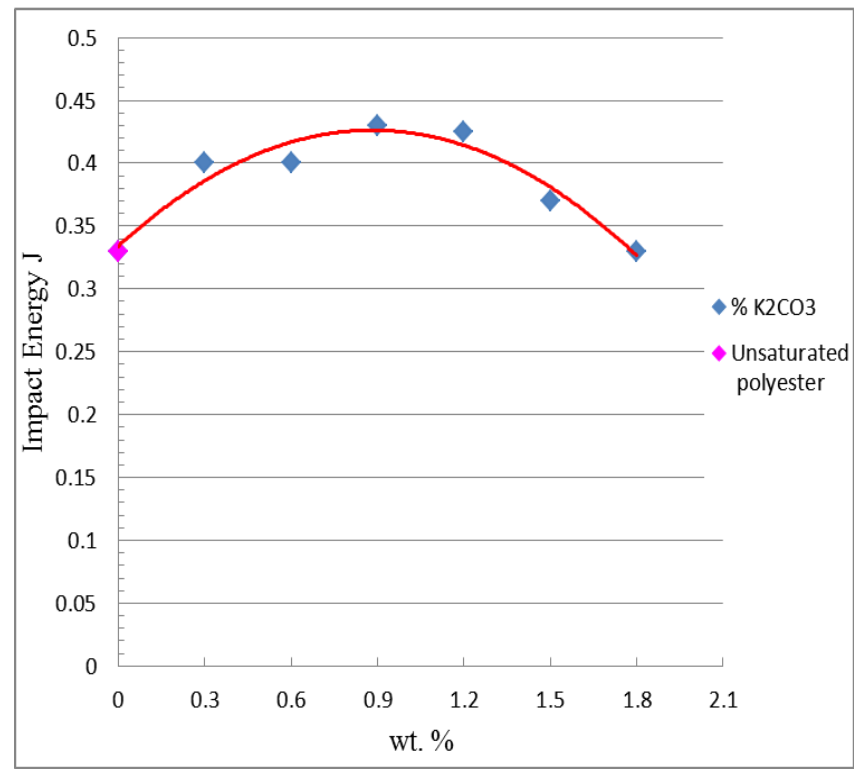

Figure 3: Relationship between the impact energy and weight fraction of the filler particles at $0.3-1.8 \mathrm{wt} \%$

\subsection{Physical Evaluation}

\subsubsection{Water Absorption}

Figure 4 illustrates the relationship between percentage of water absorption and weight fraction of $\mathrm{K}_{2} \mathrm{CO}_{3}$. Water absorption behavior of polymer-filled composites at a particular environmental condition is determined by many factors, such as processing techniques, matrix filler characteristics, composition of the composites, and duration of immersion in water [15]. The results revealed that the percentage of water absorption increased with increasing weight fraction of $\mathrm{K}_{2} \mathrm{CO}_{3}$ and reached its maximum value of $0.9831 \%$ at 1.8 wt $\%$ compared with the water absorption percentage of the reference $(0.2626 \%)$. The increase may be attributed to the filler particles with higher percentage of water absorption than the matrix material, especially $\mathrm{K}_{2} \mathrm{CO}_{3}$ which has hygroscopic nature and is very soluble in water at $1120 \mathrm{~g} / \mathrm{L}$ at $20^{\circ} \mathrm{C}$ [22]. 


\section{International Journal of Science and Research (IJSR) \\ ISSN (Online): 2319-7064}

Index Copernicus Value (2013): 6.14 | Impact Factor (2014): 5.611

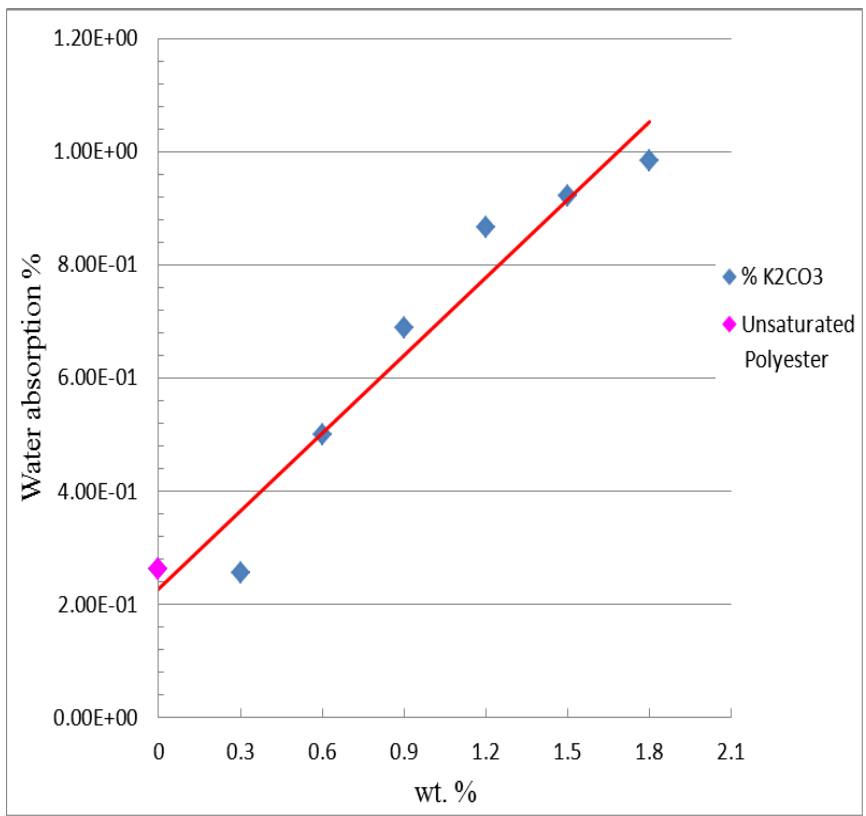

Figure 4: Relationship between water absorption percentage and weight fraction of the filler particles at 0.3-1.8 wt\%

\section{Conclusions}

Tensile strength and impact energy increased as the $\mathrm{K}_{2} \mathrm{CO}_{3}$ weight fraction increased at low particle weight range of $0.3-0.9$ wt $\%$ for prepared unsaturated polyester resin $/ \mathrm{K}_{2} \mathrm{CO}_{3}$ composites, which were higher than that of the cast neat resin. The maximum tensile strength and impact energy were observed at 0.3 and $0.9 \mathrm{wt} \% \mathrm{~K}_{2} \mathrm{CO}_{3}$, respectively, and increasing weight fraction increased tensile strength but decreased impact energy. The hardness and percentage of water absorption increased with filler percentage and reached maximum values at 1.5 and $1.8 \mathrm{wt} \%$, respectively.

\section{References}

[1] Lutton, P.P. and Ben- Nissan, B., "Mat. Tech." 12, [3-4], 119-126, 1997.

[2] Katti Ks., "Biomaterial in Total Joint Replacement" Colloids Surf. B Biointerfaces, 39: 133-142, 2004.

[3] B. S. Kim, D.J. Mooney, "Trends Biotechnol" 16, 224, 1998.

[4] J. S. Temenoff, A. G. Mikos, "Biomateials" 21, 2405, 2000.

[5] Carsten Schiller, Matthias Eppile, "Carbonated Calcium Phosphates are Suitable pH- Stabilizing Fillers for Biodegradable Polyesters" Biomaterials. Vol. 24, 2003.

[6] Roger Narayan, Editor; Biomedical Materials, Springer Science, USA, 2009.

[7] Qing Liu, Joost R. De Wijn, Clemens A. Van Blitterswijk, "Composite Biomaterials with Chemical Bonding between Hydroxyapatite Filler Particles and PEG/PBT Copolymer Matrix" Journal of Biomedical Materials Research, Volume 40, Issue 3, pages 490-497, 5 June 1998.

[8] Kai- Uwe Lewandrowski, Shrikar P. Bondre, Donald L. Wise, Debra J. Trantolo, "Enhanced Bioactivity of a Poly (Propylene Fumarate) Bone Graft Substitute by Augmentation with NanoHydroxyapatite" Bio-Medical Materials and Engineering, Volume 13, Number 2 , pages 115-124, 2003.

[9] M. Jayabalan , K.T. Shalumon, M.K. Mitha, K. Ganesan ,M. Epple ; "Effect of hydroxyapatite on the biodegradation and biomechanical stability of polyester nanocomposites for orthopaedic applications"; Acta Biomaterialia, Volume 6, Issue 3, Pages 763-775, March 2010.

[10] Kahtan Khalaf Al-khazraji, Waleed Asim Hanna, Rabab Asim Abdul-Aziz, "Preparation and Characterization of Polymer- Ceramic Composite Bio-material”, Engineering \& Technology Journal, Vol.28, No.13, Pages: 2497-2515, 2010

[11] Jaafar Al-Haidari, Engineering Materials Tests, Dar AlMotaz for publication and distribution, first edition ,Jordan, 2005

[12] Qahtan Kahlf Al-Khazraji, Adel Mahmoud Hassan, Abd El Gawad Mohamed Sharif; Engineering materials and their tests; Dar Djlah for publication and distribution, first edition, Jordan ,2009.

[13] Mohammed Ismail Omar, Quality and plastic materials tests, Dar al-kotob al-ilmiyah for Publishing and Distribution, Lebanon, 2001.

[14] Shao-Yun Fu , Xi-Qiao Feng , Bernd Lauke , Yiu-Wing Mai ,effects of particle size,particle/matrix interface adhesion and particle loading on mechanical properties of particulate-polymer composites, Elsevier, Composites part B 39 (2008) 933-961.

[15] H. V. Ramakrishna , S. K. Rai ; Effect on the Mechanical Properties and Water Absorption of Granite Powder Composites on Toughening Epoxy with Unsaturated Polyester and Unsaturated Polyester with Epoxy Resin; SAGE Publications, Journal of REINFORCED PLASTICS AND COMPOSITES, Vol. 25, No. 1,2006.

[16] Asma Yasmin, Jyi-Jiin Luo, Isaac M.Danie1. "Processing of Expanded Graphite Reinforced Polymer Nanocomposites". Composites Science and Technology, Vol.66, pp. 1 179-1 186,2006.

[17] Ganiyu K. Latinwo, David S. Aribike, Layioye O. Oyekunle, Akpoveta A. Susu , Semiu A. Kareem ; EFFECTS OF CALCIUM CARBONATE OF DIFFERENT COMPOSITIONS AND PARTICLE SIZE DISTRIBUTIONS ON THE MECHANICAL PROPERTIES OF FLEXIBLE POLYURETHANE FOAM; Nature and Science 2010;8(9): pages 92-101. (ISSN: 1545-0740).

[18] B. Shivamurthy, Siddaramaiah , M.S. Prabhuswamy ; Influence of $\mathrm{SiO}_{2}$ Fillers on Sliding Wear Resistance and Mechanical Properties of Compression Moulded Glass Epoxy Composites ; Journal of Minerals \& Materials Characterization \& Engineering, Vol. 8, No.7, pp 513-530, 2009.

[19] M.S. Sreekanth , V.A. Bambole, S.T. Mhaske, P.A. Mahanwar ; Effect of Particle Size and Concentration of Flyash on Properties of Polyester Thermoplastic Elastomer Composites ; Journal of Minerals \& Materials Characterization \& Engineering, Vol. 8, No.3, pp 237-248, 2009.

[20] M. S. Sreekanth, V. A. Bambole, S. T. Mhaske, P. A Mahanwar ; Effect of Concentration of Mica on Properties of Polyester Thermoplastic Elastomer Composites ; Journal of Minerals \& Materials Characterization \& Engineering, Vol. 8, No.4, pp 271-282, 2009

[21] Suryasarathi Bose and P.A.Mahanwar; Effect of Particle Size of Filler on Properties of Nylon-6; Journal of Minerals \& Materials Characterization \& Engineering, Vol. 3, No.1, pp 23-31, 2004.

[22] Pradyot Patnaik, Handbook of Inorganic Chemicals, McGraw-Hill Companies, Inc.2003. 